\title{
FAKTOR-FAKTOR YANG MEMPENGARUHI PEMBIAYAAN PERBANKAN SYARIAH SEKTOR INDUSTRI DI INDONESIA
}

\section{FACTORS THAT AFFECT THE FINANCING OF ISLAMIC BANKING INDUSTRY SECTOR IN INDONESIA}

\author{
Siti Nurul Kholipah'1a; Afiati Kurniasih² \\ 1aProgram Studi Ekonomi Islam Fakultas Ekonomi Islam Universitas Djuanda, Jl. Tol Ciawi \\ No.1, Kotak Pos 35 Bogor 16720 \\ 2Program Studi Perbankan Syariah Fakultas Ekonomi Islam Universitas Djuanda, Jl. Tol \\ Ciawi No. 1, Kotak Pos 35 Bogor 16720
}

(Diterima oleh Dewan Redaksi 01-01-2017)

(Dipublikasikan oleh Dewan Redaksi 20-06-2017)

\begin{abstract}
Downturn's economic of indonesia makes difficult to get capital for many econimiers, especially industrial's sector. The capital gets from finance. The finance usully gets from source of finance. The financing of islamic banking is to be way got financing not interest for industrial's sector. In the finance is looking for affected factors from the financing of islamic banking to industrial's sector. The Factors that affect the financing of Islamic banking including TPF (Third Party Funds), Equivalent Rate Murabaha (ER_M), Work Force Industry (AKI), and Non-Performing Finance sector (NPFi), inflation (INF) and Interbank Money Market Islamic Bank (SATISFIED). The research methodology used is regression approach Ordinary Least Square (OLS) using SPSS software 22. Based on the calculation and analysis of the research note that the influence of INF, DPK, ER_M, NPFi, Aki and SATISFIED against financing of Islamic banking to industrial's sector. From the analysis of the data found that the inflation factor greatly influencing the financing of Islamic banking to the industrial sector because it has a higher value on the main factors.

Keywords: Analysis, Factor, Islamic Banking, Industrial's Sector
\end{abstract}

\begin{abstract}
ABSTRAK
Penurunan Perekonomian Indonesia membuat banyak pihak ekonomi terutama sektor industri menjadi sulit untuk mendapatkan modal. Modal tersebut didapatkan melalui pembiayaan. Pembiayaan biasanya berasal dari berbagai sumber pembiayaan. Pembiayaan Perbankan Syariah menjadi salah satu alternatif dan solusi terbaik untuk mendapatkan pembiayaan yang halal dan bebas bunga kepada sektor industri. Dalam proses pembiayaan ditemukan banyak faktor yang mempengaruhi pembiayaan perbankan syariah kepada sektor industri. Faktor-faktor yang mempengaruhi pembiayaan perbankan syariah sektor industri diantaranya DPK (Dana Pihak Ketiga), Equivalent Rate Murabahah (ER_M), Angkatan Kerja industri (AKi), dan Non Performing Finance sektor industri (NPFi), Inflasi (INF) dan Pasar Uang Antar Bank Syariah (PUAS). Metodologi penelitian yang digunakan ialah regresi berganda dengan pendekatan Ordinary Least square (OLS) menggunakan sofware SPSS 22. Berdasarkan penghitungan dan analisis penelitian diketahui bahwa adanya pengaruh INF, DPK, ER_M, NPFi, AKi dan PUAS terhadap pembiayaan perbankan syariah sektor industri. Dari hasil analisis data diketahui bahwa Faktor inflasi sangat
\end{abstract}


mempengaruhi pembiayaan perbankan syariah sektor industri karena memiliki nilai lebih tinggi pada faktor utama.

Kata Kunci : Analisis, Faktor, Perbankan Syariah, Sektor Industri

Siti Nurul Kholipah. 2017. Faktor-Faktor Yang Mempengaruhi Pembiayaan Perbankan Syariah Sektor Industri di Indonesia. Jurnal Nisbah 3 (1): 351 - 364.

\section{PENDAHULUAN}

Menurut Badan Pusat Statistik (BPS), ditengah kondisi ekonomi yang semakin berkembang saat ini, perekonomian Indonesia tahun 2015 tumbuh sebesar $4.79 \%$ dibandingkan dengan tahun 2014. Pertumbuhan ekonomi tersebut diakibatkan oleh Produk Domestik Bruto (PDB). PDB merupakan tarif pasar untuk segala aktivitas ekonomi berupa barang ataupun jasa yang diproduksi oleh negara tertentu pada suatu periode. Pertumbuhan PDB tersebut salah satunya terdapat pada sektor industri. Pertumbuhan industri didukung oleh aktiva yang salah satunya disediakan perbankan syariah sebagai alternatif dan solusi permodalan untuk sektor industri. Permodalan tersebut disediakan sebagai penyaluran dana dari perbankan syariah.

Salah satu sektor ekonomi yang diberikan pembiayaan perbankan syariah yaitu sektor industri. Sektor industri yakni keseluruhan hal tentang tatanan industri. Sektor industi yang berkontribusi besar dalam pertumbuhan PDB mendapatkan porsi pembiayaan yang lebih minim dibandingkan sektor-sektor lainnya. Namun, sektor industri mendapatkan peningkatan jatah pembiayaan. Hampir setiap tahun kouta pembiayaan perbankan syariah terhadap sektor industri kurang lebih naik sebesar Rp. 1 triliun. Kenaikan sebesar Rp. 1 triliun terjadi dari tahun 2009 - 2013, dan juga terjadi dari tahun 2014 - 2015.

Pada tahun 2013 - 2014 tren pembiayaan perbankan syariah terhadap sektor industri mendapati peningkatan yang sangat signifikan. Kenaikan itu kurang lebih sebesar Rp. 7 triliun. Jika diperhatikan secara seksama, seluruh pembiayaan perbankan syariah terhadap sektor industri selalu mengalami tren yang naik tanpa adanya penurunan. Tren pembiayaan perbankan syariah terhadap sektor industri yang selalu naik tanpa ada satupun pergeseran dari tahun 2009 2015 ini tentu dipengaruhi oleh faktorfaktor tertentu.

\section{MATERI DAN METODE}

Penelitian ini memanfaatkan pendekatan statistik inferensi kuantitatif. Statistik inferensi merupakan teknik analisis dengan cara menguji hipotesis atau menarik kesimpulan. Statistik inferesial berdasarkan macam analisisnya yang digunakan yaitu analisis korelasional.

Populasi penelitian ini ialah seluruh data pembiayaan perbankan syariah sektor industri ( $\mathrm{PI}$ ), inflasi (INF), non performing financing sektor industri (NPFi), dana pihak ketiga (DPK), equivalent rate murabahah (ER_M), jumlah angkatan kerja sektor industri (AKi) dan jumlah dana yang dimiliki bank syariah di pasar uang antar bank syariah (PUAS). Sampel penelitian ini yaitu data PI, INF, NPFi, DPK, ER_M, AKi dan PUAS dari bulan Desember 2009 - Desember 2015 di Indonesia. Data yang digunakan pada penelitian ini ialah data sekunder. Data ini bersumber dari publikasi Bank Indonesia antara lain Statistik Perbankan Syariah Bank Indonesia (SPS BI), Statistik Perbankan Indonesia (SPI), Booklet Perbankan Indonesia, Laporan Profil Industri Perbankan dan Badan Pusat Statistik (BPS). Cara pengumpulan data didalam penelitian ini dengan studi literatur dan library research. 


\section{Operasional Variabel}

Pembiayaan perbankan syariah Sektor Industri adalah pengadaan dana yang berupa bisnis jual beli atau pada transaksi lain, berdasarkan mufakat kedua belah kelompok antara bank syariah dan nasabah yang diberi akomodasi dana untuk mendeportasi anggaran tersebut selepas ukuran waktu tertentu dengan margin atau nisbah akad yang lain kepada sektor industri. Menurut Iska 2012 pada bukunya yang berjudul sistem perbankan syariah pada perspektif fikih ekonomi bahwa pembiayaan perbankan syariah terdapat dalam bentuk negosiasi jual beli termasuk kepada salah satu sektor ekonomi yaitu sektor industri. Sektor industri yang menjadi ruang lingkup pembiayaan perbankan syariah atas penelitian ini yaitu sektor industri besar dan sedang (IBS).

Inflasi merupakan reaksi kenaikan harga-harga normal barang-barang secara berkelanjutan semasa periode tertentu. Menurut Adiwarman Karim 2004 pada bukunya yang berjudul Bank Islam Analisis Fiqih dan Keuangan bahwa inflasi mempengaruhi pembiayaan perbankan syariah sektor ekonomi, salah satunya sektor industri.

Non Performing Financing Sektor Industri adalah rasio pembiayaan bermasalah terhadap total pembiayaan pada sektor industri. Menurut penelitian Dahrani 2014 dalam jurnal yang berjudul Analisis Mekanisme Pembiayaan Mudharabah Pada PT.Bank BNI Syariah Kantor Cabang Medan bahwa Non Performing Financing berpengaruh terhadap pembiayaan perbankan syariah pada sektor ekonomi, salah satu sektor ekonomi yaitu sektor industri.

Pasar Uang Antar Bank Syariah ialah aktivitas pembicaraan keuangan pasar pendek antara peserta pasar berdasarkan asas-asas syariah. Menurut Fatwa DSN no 37 bahwa PUAS disalurkan dananya kepada pembiayaan perbankan syariah sektor ekonomi, salah satunya sektor industri.
Equivalent Rate Murabahah merupakan indikasi tingkat balasan dari suatu pemodalan dana bank pelopor pada transaksi jual beli. Menurut laporan Statistik Perbankan syariah 2015 bahwa Equivalent Rate Murabahah yang paling banyak digunakan dalam pembiayaan perbankan syariah pada sektor ekonomi, salah satunya sektor industri.

Angkatan Kerja Sektor Industri adalah penduduk di umur angkatan kerja yang sedang bekerja pada sektor industri. Menurut penelitian hutasuhut 2006 pada jurnalnya yang berjudul Analisis FaktorFaktor Yang Mempengaruhi Pertumbuhan Industri Non Migas Di Provinsi Sumatera Utara bahwa angkatan kerja sektor industri menggambarkan faktor produksi yang mempengaruhi perkembangan industri.

Dana Pihak Ketiga merupakan persediaan pendapatan yang berawal dari masyarakat dalam berbagai produk simpanan yang dipunyai oleh bank. Menurut Iska 2012 pada bukunya yang berjudul sistem perbankan syariah pada perspektif fikih ekonomi bahwa dana pihak ketiga mempengaruhi pembiayaan perbankan syariah.

\section{Teknik Analisis Data}

Teknik analisis data yang difungsikan pada penelitian ini menggunakan Regresi Berganda dengan pendekatan Ordinary Least Square (OLS) menggunakan sofware SPSS 22 (Statistical Package for the Social Sciences). Sebelum melakukan interpretasi atas analisis regresi yang direaksikan maka hendaknya harus melakukann beberapa langkah yaitu uji asumsi klasik dan kelayakan model lantaran uji asumsi klasik membenarkan bahwa kondisi minimum sebuah acuan regresi linier (melalui pendekatan OLS) telah dikomprehensif sehingga tidak akan memunculkan kekeliruan dalam pemenuhan asumsi. 


\section{Uji Asumsi Klasik}

Multikolenier yaitu salah satu pengujian bagi analisis regresi berganda dimana terjadi korelasi antara variabel independen. Setiap variabel diharapkan dapat berkorelasi yang tinggi antara variabel X dengan variabel Y. Salah satu kaidah untuk mengidentifikasi keberadaan multikolinear yaitu tolerence. Tolerence yaitu ukuran yang menunjukkan besarnya variabilitas variabel independen khusus yang tidak diterangkan untuk variabel independen lainnya. Tolerence yang tinggi mengidentifikasikan multikolenier yang rendah.

Cek asumsi independensi ialah uji asumsi mengindikasikan bahwa asumsi y independen terpenuhi. Salah satu hipotesis bermula model regresi linier, maka tak ada autokorelasi atau korelasi serial antara sisaan $(\varepsilon t)$.

Homoskedastisitas artinya semua faedah regresi populasi memegang varian yang sama yaitu $\sigma^{2}$. Jika varian tersebut tidak sama maka asumsi pada penelitian ini menghadapi situasi heteroskedastisitas atau varian tidak sama (non konstan).

Uji normalitas diuntungkan untuk menyelidiki informasi yang digunakan mengikuti berdiseminasi normal atau tidak. Tujuan dari uji normalitas yaitu untuk mengetahui pembagian sebuah data berjalan mendekati atau mengikuti distribusi normal.

\section{Uji Kelayakan Model}

Uji-F merupakan alat analisis untuk menguji pengaruh variabel bebas terhadap variabel terikat secara keseluruhan. Pengujian F ini dapat dilihat dari peluang statistik-F. Hal ini dapat diamati dengan menggunakan rumus dibawah ini:

$$
F=\frac{\mathrm{R}^{2} /(\mathrm{k}-1)}{\left(1-\mathrm{R}^{2}\right) /(\mathrm{n}-\mathrm{k})}
$$

$$
\begin{array}{ll}
\text { Keterangan: } \\
R^{2} \quad=\text { Koefisien Determinasi } \\
\mathrm{K} \quad=\text { Banyak Parameter Termasuk } \\
\quad \text { Konstanta } \\
\mathrm{N} \quad=\text { Jumlah Sampel }
\end{array}
$$

Regresi berganda merupakan teknik statistika yang bisa difungsikan selama menganalisis hubungan sekitar variabel dependen dan variabel independen dengan desain kuadrat terkecil (OLS). OLS merupakan kaidah kuadrat terkecil dalam regresi. Kuadrat terkecil ini merupakan variabel yang mempengaruhi dalam penelitian ini. Variabel yang mempengaruhi dalam penelitian ini diantaranya yaitu INF, NPFi, PUAS, AKi, ER_M, dan DPK. Variabel tersebut akan membentuk model linear. Model tersebut belum linear sehingga semua variabel diubah menjadi karakter logaritma natural

\begin{tabular}{|c|c|}
\hline $\ln P_{I}$ & : Pembiayaan Perbankan \\
\hline & Syariah Ke Sektor Industri \\
\hline & Besar dan Sedang \\
\hline $\ln I N F$ & : Inflasi \\
\hline $\ln N P F i$ & $\begin{array}{l}\text { Non Performing Financing } \\
\text { sektor industri }\end{array}$ \\
\hline $\ln$ PUAS & $\begin{array}{l}\text { : Dana yang dimiliki } \\
\text { perbankan syariah di Pasar } \\
\text { Uang Antar Bank Syariah }\end{array}$ \\
\hline lnER_M & : Equivalent Rate Murabahah \\
\hline $\ln A K_{\mathrm{i}}$ & $\begin{array}{l}\text { : Jumlah Angkatan Kerja } \\
\text { Sektor Industri }\end{array}$ \\
\hline $\operatorname{lnDPK}$ & : Dana Pihak Ketiga \\
\hline a & : Konstanta \\
\hline b1,..bn & : Slope \\
\hline$\varepsilon n$ & : Resudial \\
\hline
\end{tabular}
(ln). Berikut ini adalah Model OLS :

$\ln \mathrm{P}_{\mathrm{I}}=\mathrm{a}+\mathrm{b} 1 \ln \mathrm{INF}+\mathrm{b} 2 \ln \mathrm{NPFi}+\mathrm{b} 3$ lnPUAS+ b4 lnER_M+ b5 $\ln A K i+$ b6 $\ln D P K$ $+\varepsilon n$

\section{Keterangan :}

Uji-t memiliki pengertian sebagai menguji hipotesis statistik tentang tiaptiap koefisien berganda secara sendirisendiri. Uji-t juga digunakan untuk mengukur interval atau signifikan keyakinan pada tiap-tiap variabel independen yaitu INF, NPFi, AKi, ER_M, DPK dan PUAS terhadap variabel dependen yaitu PI. Uji-t juga diperankan untuk mengetahui analisis perbedaan antara variabel independen dengan 
memenuhi syarat sebagai berikut yaitu variabel normal didistribusikan secara populasi, terdapat perbedaan yang sama antara variabel, datanya interval dan bebas dibawah ini adalah rumus uji-t: (Brink 2000:225)

$$
\begin{aligned}
& t=\frac{\bar{X}_{D}-\mu_{0}}{s_{D} / \sqrt{n}} . \\
& \bar{X}_{d}=\frac{\sum D}{n} \\
& s_{d}=\sqrt{\frac{1}{n-1}\left\{\sum D^{2}-\frac{\left(\sum D\right)^{2}}{n}\right\}}
\end{aligned}
$$

Keterangan

$$
\begin{array}{ll}
\mathrm{D} & =\text { Selisih } \mathrm{x} 1 \text { dan } \mathrm{x} 2(\mathrm{x} 1-\mathrm{x} 2) \\
\mathrm{n} & =\text { Jumlah Sampel } \\
\mathrm{X} \text { bar } & =\text { Rata-rata } \\
\mathrm{S} \mathrm{d} & =\text { Standar Deviasi dari d }
\end{array}
$$

Penelitian ini menggunakan uji koefisien determinasi yang memiliki pengertian untuk menanggapi seberapa erat interaksi antara variabel. Selain itu koefisien determinasi untuk mengetahui analisis korelasi antara variabel dependen dengan variabel independen. Simbol dari koefisien determinasi yaitu $\mathrm{r}^{2}$. Koefisien determinasi memiliki pengertian semacam alat ukur untuk mengukur ketepatan suatu model melalui formula sebagai berikut:

$$
R^{2}=1-\frac{S S \text { Eror }}{S S \text { Total }}=1-\frac{\sum\left(y_{i}-\hat{y}_{i}\right)^{2}}{\sum\left(y_{i}-\bar{y}\right)^{2}}
$$

$$
\begin{aligned}
& \text { Keterangan : } \\
& y_{i}=\text { observasi respon } k \mathbf{e}-\mathbf{i} \\
& \bar{y}=\text { rata }- \text { rata } \\
& \hat{y}_{i}=\text { ramalan respon } \mathbf{k e}-\mathbf{i}
\end{aligned}
$$

Interpretasi yang dilakukan terhadap koefisien regresi meliputi dua hal, tanda dan besaran. Tanda menentukan arah hubungan. Tanda dapat bermutu positif atau negatif. Positif menetapkan pengaruh yang searah antara variabel bebas terhadap variabel terikat, sedangkan negatif mengacu pengaruh yang berlawanan arah.

\section{HASIL DAN PEMBAHASAN}

\section{Perkembangan Perbankan Syariah}

Berdasarkan Laporan Profil Industri Perbankan Triwulan III tahun 2015 bahwa aktivitas industri perbankan syariah tergolong real sektor driven dimana penurunan kinerja sektor riil akan berefek langsung kepada kinerja perbankan syariah, termasuk berpengaruh terhadap kemajuan aset dan pembiayaan perbankan syariah. Keaktifan aset, DPK, dan pembiayaan industri perbankan syariah pada triwulan III-2015 dibandingkan triwulan II-2015 mengalami peningkatan masing-masing sebesar $3,17 \%$ (qtq), 2,73\% (qtq), dan 1,01\% (qtq).

Ditengah kondisi perekonomian domestik, perbankan syariah merujuk tingkat permodalan yang baik. Kinerja permodalan BUS pada triwulan III tahun 2015 mengalami peningkatan yang ditunjukkan dengan CAR yang meningkat dari triwulan sebelumnya yaitu dari $14,09 \%$ menjadi $15,15 \%$. Peningkatan tersebut dikarenakan siapnya peningkatan modal dan penurunan ATMR (Aktiva Tertimbang Menurut Risiko).

Pada triwulan III-2015 pertumbuhan DPK mengalami kualitas sebesar 2,73\% (qtq) dibandingkan pada triwulan sebelumnya. Peningkatan tersebut difaktorkan oleh pertumbuhan pada tabungan murabahah $(4,75 \%$, qtq) dan deposito murabahah $(3,22 \%$, qtq), sementara giro wadiah mengalami anjlok sebesar $5,75 \%$ (qtq).

Likuiditas BUS pada triwulan II I2015 mengalami peningkatan. Hal tersebut terlihat dari rasio AL/NCD (Alat Likuid/Non Core Deposit) BUS yang meningkat dari 86,30\% (24 Juni 2015) menjadi 107,43\% (30 September 2015). Begitu juga pada rasio AL/DPK BUS mengalami peningkatan dari 15,32\% (24 Juni 2015) menjadi 19,04\% (30 September 2015). Penyaluran pembiayaan BUS dan UUS pada triwulan III-2015 meningkat Rp2,1 triliun (1,01\%, qtq) dari Rp206,1 triliun menjadi Rp208,1 triliun. 
Rentabilitas BUS pada triwulan III2015 mengalami sedikit penurunan dibandingkan pada triwulan II-2015 yang tampak dari penurunan rasio ROA (Return on Assets) dan Net Operating Margin (NOM) BUS. ROA BUS pada triwulan ini turun menjadi $0,49 \%$ dibandingkan triwulan sebelumnya sebesar $0,50 \%$.

Jumlah bank umum syariah pada tahun 2009 sebanyak 6 naik menjadi 12 sampai tahun 2015. Jumlah karyawan perbankan syariah pada tahun 2009 sebanyak 10.345 juta jiwa menjadi 38.307 juta jiwa di tahun 2015. Giro Wadiah mengalami perkembangan dengan kenaikan dari tahun 2009 sampai dengan tahun 2015 sebesar 8.337 Milyar Rupiah. SBIS pada tahun 2009 sebesar 3.076 Milyar Rupiah dan pada tahun 2015 sebesar 8.858 Milyar Rupiah.

Pembiayaan mudharabah mengalami perkembangan dengan memuncak dari tahun 2009 sampai dengan 2015 sebesar 8.226 Milyar Rupiah. Pembiayaan musyarakah mengalami perkembangan dengan menanjak dari tahun 2009 sampai dengan 2015 sebesar 50.301 Milyar Rupiah. Pembiayaan murabahah mengalami perkembangan dengan meninggi dari tahun 2009 sampai dengan 2015 sebesar 101.790 Milyar Rupiah. Pembiayaan istisna mengalami perkembangan dengan kenaikan dari tahun 2009 sampai dengan 2015 sebesar 347 Milyar Rupiah. Pembiayaan ijarah mengalami perkembangan dengan kenaikan dari tahun 2009 sampai dengan 2015 sebesar 9.326 Milyar Rupiah. Pembiayaan Qard mengalami perkembangan yang umggul pada tahun 2011 dengan jumlah pembiayaan sebesar 12.937 Milyar Rupiah.

Pembiayaan perbankan syariah untuk modal kerja mengalami perkembangan dengan kenaikan dari tahun 2009 sampai dengan 2015 sebesar 57.076 Milyar Rupiah. Pembiayaan untuk investasi mengalami perkembangan dengan kenaikan dari tahun 2009 sampai dengan 2015 sebesar 41.735 Milyar
Rupiah. Pembiayaan perbankan syariah untuk konsumsi mengalami perkembangan dengan kenaikan dari tahun 2009 sampai dengan 2015 sebesar 67.299 Milyar Rupiah.

Pembiayaan perbankan syariah untuk usaha kecil dan menengah mengalami perkembangan dengan pembiayaan terbesar pada tahun 2013 sebesar $110.086 \quad$ Milyar Rupiah. Pembiayaan perbankan syariah untuk selain kecil dan menengah mengalami perkembangan dengan kenaikan dari tahun 2009 sampai dengan 2015 sebesar 141.204 Milyar Rupiah.

\section{Analisis Penelitian}

Penghitungan pada penelitian ini dengan teknik analisis berganda pendekatan OLS menggunakan software SPSS 22. Data-data yang digunakan dalam penelitian ini berasal dari Bank Indonesia dan Badan Pusat Statistik. Data-data tersebut terdiri dari data-data inflasi, non performing financing sektor industri, dana yang dimiliki bank syariah di PUAS syariah, equivalent rate murabahah, jumlah angkatan kerja sektor industri, dana pihak ketiga dan pembiayaan perbankan syariah sektor industri. Sektor industri yang menjadi ruang lingkup pembiayaan perbankan syariah pada penelitian ini yaitu sektor industri besar dan sedang (IBS). Data-data pada penelitian ini diambil dari bulan desember 2009 sampai dengan desember 2015. Agar data-data tersebut ekuivalen, maka data inflasi, non performing financing sektor industri, dana yang dimiliki bank syariah di pasar uang antar bank syariah, equivalent rate, jumlah angkatan kerja sektor industri, dana pihak ketiga dan pembiayaan perbankan syariah sektor industri bentuknya telah ditransformasi menjadi logaritma natural (ln) sehingga variabel tersebut dapat menjadi linear dan dapat diukur fungsinya setiap variabel. Berikut adalah hasil dari logit setiap variable. 
Tabel 1. Variabeles Entered/Removed

\begin{tabular}{|l|l|r|r|}
\hline Model & \multicolumn{1}{|c|}{$\begin{array}{c}\text { Variables } \\
\text { Entered }\end{array}$} & $\begin{array}{r}\text { Variabels } \\
\text { Removed }\end{array}$ & Method \\
\hline 1 & ln_DPK & & Enter \\
& ln_ER_M & & \\
& ln_INF & & \\
& ln_NPFi & & \\
& ln_AKi & & \\
& ln_PUAS & & \\
\hline
\end{tabular}

Sumber : Hasil pengolahan SPSS 22

Sebelum melakukan interpretasi atau penafsiran atau penjelasan atas analisis regresi yang dihasilkan seharusnya dilakukan setelah semua tahapan yaitu uji asumsi klasik dan kelayakan model karena uji asumsi klasik memastikan bahwa persyaratan minimal sebuah model regresi linier (dengan pendekatan OLS) telah dipenuhi sehingga tidak akan menimbulkan kesalahan dalam pemenuhan asumsi. Apabila uji asumsi klasik belum terpenuhi besar kemungkinan interpretasi model menjadi bias atau kurang tepat, uji kelayakan memastikan bahwa model regresi linier yang diestimasi memang layak menjelaskan pengaruh variabel bebas terhadap variabel terikat. Apabila model yang diestimasi tidak atau kurang layak, maka model tersebut memang tidak bisa digunakan untuk menafsirkan (interpretasi) pengaruh variabel bebas terhadap variabel terikat.

\section{Uji Asumsi Klasik}

Uji multikolinearitas untuk mengetahui apakah terjadi korelasi yang kompeten di antara variabel-variabel independen yang diikutsertakan dalam format model. Untuk mendeteksi apakah model regresi linear mengalami multikolinearitas dapat diperiksa menggunakan Variance Inflation Factor (VIF) untuk masing-masing variabel independen mempunyai nilai VIF $>10$ berarti telah terjadi multikolinearitas. Dibawah ini adalah output untuk uji multikolinearitas.
Tabel 2. Coefficients ${ }^{\mathrm{a}}$

\begin{tabular}{|c|l|c|c|}
\hline \multirow{2}{*}{ Model } & \multicolumn{2}{c|}{ Collinearity Statistics } \\
\cline { 2 - 4 } & \multicolumn{2}{c|}{ Tolerance } & VIF \\
\hline \multirow{4}{*}{1} & In_INF &, 76 & 1,32 \\
\cline { 2 - 4 } & In_NPFi &, 25 & 4,03 \\
\cline { 2 - 4 } & ln_PUAS &, 10 & 10,40 \\
\cline { 2 - 4 } & ln_ER_M &, 88 & 1,14 \\
\cline { 2 - 4 } & ln_Aki &, 20 & 5,03 \\
\cline { 2 - 4 } & ln_DPK &, 09 & 11,44 \\
\hline
\end{tabular}

a. Dependent Variable: $\ln \_\mathrm{PI}$ Sumber : Hasil pengolahan SPSS 22

Berdasarkan hasil output SPSS diketahui nilai VIF dari variabel inflasi, NPF sektor industri, equivalent rate murabahah, dan angkatan kerja sektor industri masing-masing sebesar 1,32; 4,03; 1,14; 5,03 kurang dari 10 berarti tidak terjadi multikolinearitas. Variabel dana bank syariah di PUAS dan Dana Pihak Ketiga masing-masing sebesar 10,40 dan 11,44 lebih besar dari 10 berarti sudah terbentuk multikolinearitas.

Cek asumsi independensi dapat divisualisasikan dari plot residual terstandar dan variabel dependen sebagai berikut :

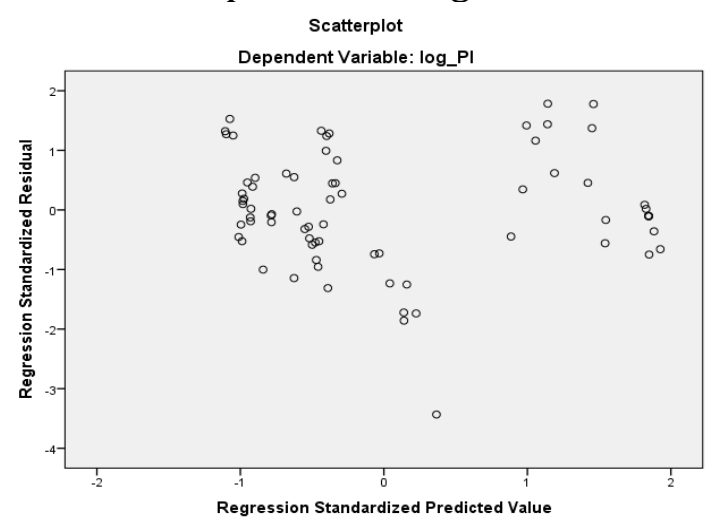

Gambar 1. Plot Residual VS Dependen

Dari gambar Plot Residual VS Dependen nampak bahwa sebaran data cenderung menyebar dan tidak membentuk pola tertentu. Hal ini mengindikasikan bahwa asumsi y independen dipenuhi. Artinya pada variabel inflasi, non performing financing sektor industri, dana yang dimiliki bank syariah di PUAS, equivalent rate murabahah, jumlah angkatan kerja sektor industri, dan dana pihak ketiga dapat dipenuhi sebagai variabel bebas.

Cek asumsi homogenitas dapat divisualkan dari plot residual dan variabel prediktor seperti gambar dibawah ini: 


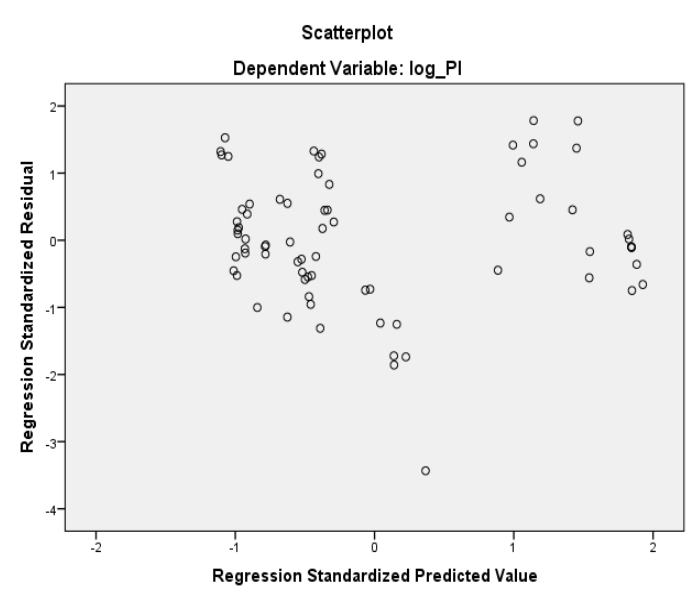

Gambar 2. Plot Residual vs prediktor

Berdasarkan gambar plot residual vs prediktor dapat diketahui bahwa sebaran titik tidak membentuk suatu pola/alur tertentu sehingga dapat disimpulkan tidak terjadi heteroskedastisitas atau terjadi homoskedastisitas yang artinya semua fungsi regresi populasi memiliki varian yang sama yaitu $\sigma^{2}$. Asumsi klasik tentang heteroskedastisitas dalam model ini terpenuhi yaitu bebas dari heteroskedastisitas.

Cek asumsi kenormalan dapat dilihat dari plot normal sebagai berikut :

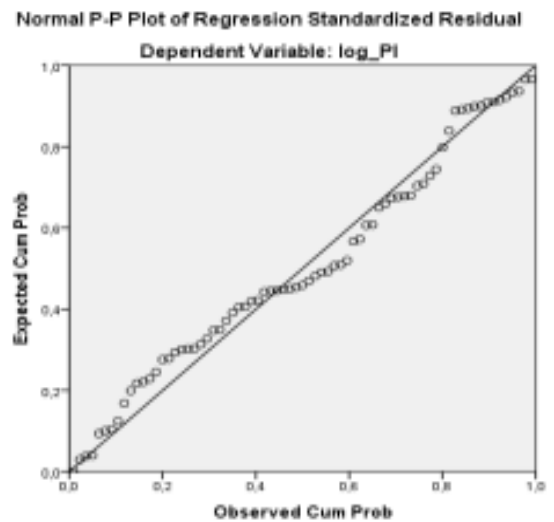

Gambar 3. Hasil Uji Normalitas dengan SPSS 22

Berdasarkan gambar hasil uji normalitas dapat diketahui sebaran titiktitik dari gambar Normal P-P Plot relatif membentuk garis lurus, sehingga dapat disimpulkan (data) residual terdistribusi normal. Oleh karenanya, data-data inflasi, non performing financing sektor industri, dana yang dimiliki bank syariah di PUAS, equivalent rate murabahah, jumlah angkatan kerja sektor industri, dana pihak ketiga dan pembiayaan perbankan syariah sektor industri sudah berdistribusi normal dan dapat digunakan pada penghitungan regresi berganda dengan pendekatan OLS.

Berdasarkan hasil uji klasik pada penelitian ini bahwa telah memenuhi syarat uji asumsi klasik yaitu multikolinearitas, autokorelasi (cek asumsi indepemd, cek asunsi homogenitas dan cek asumsi kenormalan.

\section{Cek Kelayakan Model}

Uji hipotesis secara keseluruhan diketahui dengan membandingkan nilai $F_{\text {hitung dengan nilai } F_{\text {tabel. }} \text { Aturan }}$ keputusannya jika nilai $F_{\text {hitung }}$ lebih besar dari $\mathrm{F}_{\text {tabel, }}$ maka hipotesis penelitian secara keseluruhan diterima (signifikan). Dibawah ini tabel anova yang menunjukkan hipotesis keseluruhan. Tabel 3. Tabel anova

\begin{tabular}{|l|c|c|c|}
\hline \multicolumn{2}{|c|}{ Model } & F & Sig. \\
\hline \multirow{3}{*}{1} & Regression & 551,20 &, $000^{\mathrm{b}}$ \\
\cline { 2 - 4 } & Residual & & \\
\cline { 2 - 4 } & Total & & \\
\hline
\end{tabular}

Sumber : Hasil Pengolahan data SPSS 22

Nilai prob $\mathrm{F}$ hitung pada tabel diatas yaitu 0,000 lebih kecil dari tingkat signifikasi sehingga disimpulkan, model regresi linier yang diestimasi layak digunakan untuk menjelaskan pengaruh DPK (Dana Pihak Ketiga), Equivalent Rate murabahah (ER_M), Non Performing Financing sektor industri (NPFi) dan Jumlah Angkatan Kerja sektor industri (AKi). Pasar Uang Antar Bank Syariah (PUAS) dan tingkat inflasi (INF) terhadap variabel terikat Pembiayaan Perbankan Syariah pada sektor Industri (PI).

Berdasarkan tabel diatas diperoleh $\mathrm{F}$ hitung senilai 551,20 dan tabel distribusi $\mathrm{F}$ senilai 4,28. Karena $F$ hitung senilai 551,20 lebih besar dari $F$ tabel senilai 4,28 maka $\mathrm{H}_{0}$ ditolak. Dari pernyataan diatas maka diperoleh hasil analisis bahwa model diatas dapat memprediksi pembiayaan perbankan syariah sektor industri. Maka disimpulkan bahwa variabel inflasi (INF), non performing financing sektor industri (NPFi), dana yang dimiliki bank syariah di pasar uang antar bank syariah (PUAS), equivalent rete mudharabah (ER_M), jumlah angkatan 
kerja sektor industri (AKi) dan dana pihak ketiga (DPK) secara simultan (bersamasama) berpengaruh terhadap variabel pembiayaan perbankan syariah sektor industri (PI). Sektor industri yang menjadi ruang lingkup pembiayaan perbankan syariah pada penelitian ini yaitu sektor industri besar dan sedang (IBS).

Uji hipotesis secara individual diketahui membandingkan dengan nilai $t_{\text {hitung dengan }} t_{\text {tabel. }}$ Aturan keputusannya jika nilai $t_{\text {hitung }}$ lebih besar dari $t_{\text {tabel, }}$, maka hipotesis penelitian secara individual diterima (signifikan). jika nilai thitung lebih kecil dari $t_{\text {tabel, }}$ maka hipotesis penelitian secara individual ditolak (tidak signifikan). Penentuan nilai tabel didasarkan kepada taraf kesalahan (5\% atau 1\%) dan jumlah populasi penelitian.

Tabel 4. Coefisient a

\begin{tabular}{|l|l|l|}
\hline \multicolumn{1}{|c|}{ Model } & \multicolumn{1}{c|}{ T } & \multicolumn{1}{c|}{ Sig. } \\
\hline (Constan) & $-1,14$ & 0,26 \\
\hline ln_INF & $-2,17$ & 0,03 \\
\hline ln_NPFi & 17,28 & 0,00 \\
\hline ln_PUAS & 0,62 & 0,54 \\
\hline ln_ER_M & 1,01 & 0,32 \\
\hline ln_AKi & 0,33 & 0,74 \\
\hline ln_DPK & 7,36 & 0,00 \\
\hline
\end{tabular}

Sumber : Hasil Pengolahan data SPSS 22

Berdasarkan output SPSS pada tabel coefficient nilai thitung (0,05:72) untuk inflasi $\left(\mathrm{X}_{1}\right)$ sebesar $-2,17$ dan nilai tabel sebesar 1,94. Menurut Muhammad iqbal dalam PDF-nya yang berjudul pengolahan data dengan regresi linear berganda bahwa tanda negatif memberikan pengaruh yang berlawanan arah. Berlawanan arah maksudnya apabila variabel bebas dalam hal ini inflasi mengalami kenaikan atau peningkatan atau bertambah maka variabel terikat dalam hal ini pembiayaan perbankan syariah sektor industri akan mengalami hal yang sebaliknya yaitu penurunan atau pengurangan. Sebaliknya apabila variabel inflasi mengalami penurunan maka pembiayaan perbankan syariah sektor industri akan mengalami peningkatan. Jadi, secara parsial atau individual inflasi memberikan pengaruh negatif atau berlawanan arah signifikan terhadap pembiayaan perbankan syariah sektor industri. Kemudian menurut Adiwarman Karim 2008 pada bukunya yang berjudul Bank Islam Analisis Fiqih dan Keuangan bahwa inflasi memberikan pengaruh yang negatif terhadap pembiayaan perbankan syariah sektor industri. Artinya inflasi akan memberikan pengaruh yang bertentangan dengan pembiayaan perbankan syariah. Jadi semakin besar inflasi akan menurunkan pembiayaan perbankan syariah terhadap sektor industri. Begitu pula sebaliknya semakin kecil inflasi akan meningkatkan pembiayaan perbankan syariah sektor industri. Sektor industri yang menjadi ruang lingkup pembiayaan perbankan syariah pada penelitian ini yaitu sektor industri besar dan sedang (IBS).

Nilai thitung untuk Non Performing Financing sektor industri $\left(\mathrm{X}_{2}\right)$ sebesar 17,28 dan nilai $t_{\text {tabel }}$ sebesar 1,94. Menurut Latan pada bukunya yang berjudul Analisis Multivariat Teknik dan Aplikasi Penggunaan Program SPSS 20, jika dikontektualkan tidak reliabel, mengingat jumlah Non Performing Financing sektor industri tidak mungkin positif karena secara faktanya kredit macet akan berpengaruh negatif kepada pembiayaan perbankan syariah. Apabila Non Performing Financing sektor industri naik maka pembiayaan perbankan syariah menurun dikarenakan conterparty atau perusahaan industri tidak dapat mengembalikan dananya secara lancar kepada bank syariah. Bank syariah sulit memberikan pembiayaan dikarenakan dana yang diinvestasikan pada sektor rill yaitu salah satunya sektor industri tidak dapat dikembalikan sesuai dengan kesepakatan yang telah ditentukan kedua belah pihak. dengan terjadinya Non Performing Financing sektor industri akan menurunkan pembiayaan perbankan syariah. (Latan 2013:84, Pramesti 2014:127)

Nilai $t_{\text {hitung }}(0,05: 72)$ untuk dana bank syariah pada PUAS $\left(\mathrm{X}_{3}\right)$ sebesar 0,62 dan 
nilai $t_{\text {tabel }}$ sebesar 1,94. Menurut Fatwa DSN No. 37 dan Iska 2012 pada bukunya yang berjudul Sistem Perbankan Syariah Di Indonesia dalam Perspektif Fikih Ekonomi bahwa secara parsial atau individual dana bank syariah pada PUAS memberikan pengaruh negatif signifikan terhadap pembiayaan perbankan syariah sektor industri. Dana yang dimiliki bank syariah di PUAS tidak akan memberikan pengaruh yang signifikan terhadap pembiayaan perbankan syariah sektor industri. Hal ini bisa saja berpeluang mempengaruhi kepada sektor ekonomi yang lainnya.

Nilai thitung (0,05:72) untuk Equivalent Rate Murabahah $\left(\mathrm{X}_{4}\right)$ sebesar 1,01 dan nilai tabel sebesar 1,94 . Jadi, secara parsial atau individual Equivalent Rate Murabahah memberikan pengaruh negatif signifikan terhadap pembiayaan perbankan syariah sektor industri. Menurut Statistik Perbankan Syariah 2015 bahwa pada variabel equivalent rate murabahah berpengaruh terhadap pembiayaan perbankan syariah. Akan tetapi pada hasil penelitian bahwa Equivalent Rate Murabahah tidak berpengaruh signifikan terhadap pembiayaan perbankan syariah sektor industri. Artinya equivalent rate murabahah tidak mempengaruhi pembiayaan perbankan syariah sektor industri akan tetapi kemungkinan akad yang lain dari equivalent rate selain murabahah akan mempengaruhi pembiayaan perbankan syariah sektor industri.

Nilai thitung (0,05:72) untuk Angkatan Kerja sektor industri $\left(\mathrm{X}_{5}\right)$ sebesar 0,33 dan nilai $t_{\text {tabel }}$ sebesar 1,94 . Jadi, secara parsial atau individual Angkatan Kerja sektor industri memberikan pengaruh negatif signifikan terhadap pembiayaan perbankan syariah sektor industri. Menurut penelitian Hutasuhut pada jurnalnya yang berjudul Analisis FaktorFaktor Yang Mempengaruhi Pertumbuhan Industri Non Migas di Provinsi Sumatera Utara bahwa variabel jumlah angkatan kerja sektor industri tidak berpengaruh signifikan terhadap pembiayaan perbankan syariah. Artinya angkatan kerja sektor industri berpengaruh tetapi tidak signifikan terhadap pembiayaan perbankan syariah sektor industri.

Nilai thitung (0,05:72) untuk Dana Pihak Ketiga $\left(X_{6}\right)$ sebesar 7,36 dan nilai $t_{\text {tabel }}$ sebesar 1,94. Menurut Iska 2012 pada bukunya yang berjudul Sistem Perbankan Syariah Di Indonesia dalam Perspektif Fikih Ekonomi bahwa secara parsial atau individual dana pihak ketiga memberikan pengaruh positif signifikan terhadap pembiayaan perbankan syariah sektor industri. Pada variabel dana pihak ketiga berpengaruh signifikan terhadap pembiayaan perbankan syariah. Artinya semakin tinggi dana pihak ketiga maka semakin tinggi pula pembiayaan perbankan syariah sektor industri. Begitu pula sebaliknya, semakin rendah dana pihak ketiga maka semakin kecil pembiayaan perbankan syariah sektor industri.

Dibawah ini adalah tabel koefisien determinasi.

Tabel 5. Nilai Koefisien Determinasi

\begin{tabular}{|l|c|}
\hline \multicolumn{1}{|c|}{ Variabel } & Unstandardized Coefficients \\
\hline ln_INF & $-135,05$ \\
\hline ln_NPFi & 12,12 \\
\hline ln_PUAS &, 06 \\
\hline ln_ER_M & 12,09 \\
\hline $\ln$ Aki & 67,45 \\
\hline ln_DPK &, 04 \\
\hline
\end{tabular}

Sumber : Hasil Pengolahan data SPSS 22

Berdasarkan output SPSS nilai konstanta untuk kolom Unstandardized Coefficients $B$ adalah sebesar -3097,21 sebagai alfa $(\alpha)$ diketahui nilai inflasi sebesar 135,05 nilai Non Performing Financing sektor industri sebesar 12,12 nilai dana yang dimiliki bank syariah di PUAS sebesar 0,06 nilai Equivalent Rate Murabahah sebesar 12,09 nilai Angkatan Kerja Sektor Industri sebesar 67,45 dan nilai Dana Pihak Ketiga sebesar 0,04. Persamaan regresi tersebut menunjukkan adanyan kontribusi dari kuat lemahnya inflasi, NPF sektor industri, dana bank 
syariah di PUAS, equivalent rate murabahah, angkatan kerja sektor industri dan dana pihak ketiga terhadap pembiayaan perbankan syariah sektor industri.

Menurut latan pada bukunya yang berjudul Analisis Multivariat Teknik dan Aplikasi Penggunaan Program SPSS 20 pembiayaan perbankan syariah pada sektor industri sebesar -3097,207 jika Inflasi, Non Performing Financing sektor industri, dana yang dimiliki bank syariah di PUAS, equivalent rate murabahah, jumlah angkata kerja sektor industri dan dana pihak ketiga sama dengan 0 . Tentunya hal ini jika dikonteksualkan tidaklah reliabel, mengingat jumlah pembiayaan perbankan syariah pada sektor industri tidak mungkin negatif. (latan 2013:50)

Koefisien regresi inflasi bernilai negatif. Menurut Adiwarman Karim pada bukunya yang berjudul Bank Islam Analisis Fiqih dan Keuangan bahwa Koefisien regresi Inflasi bernilai negatif artinya pada saat inflasi (ln_INF) naik maka pembiayaan perbankan syariah sektor industri (ln_PI) akan mengalami penurunan. Begitu pula pada saat inflasi (ln_INF) turun maka pembiayaan perbankan syariah sektor industri (ln_PI) akan naik. Kenaikan Inflasi (ln_INF) 1 persen akan menurunkan pembiayaan perbankan syariah sektor industri (ln_PI) sebesar 135,05 Milyar Rupiah dan sebaliknya, penuruhan Inflasi (ln_INF) 1 persen akan menurunkan pembiayaan perbankan syariah sektor industri (ln_PI) sebesar 135,05 Milyar Rupiah. Kenaikan harga-harga secara global atau makro akan menyebabkan pembiayaan perbankan syariah pada sektor industri menurun dikarenakan counterparty atau nasabah atau perusahaan industri harus menaikkan harga barang produksi. Disisi lain inflasi juga berpengaruh kepada masyarakat yang menyebabkan daya beli masyarakat menurun. Dengan penurunan daya beli masyarakat akan menurunkan keuntungan perusahaan sektor industri yang mana barang produksinya tidak terjual sebagaimana mestinya. Hal ini dapat akan merugikan perusahaan sektor industri dan juga pembiayaan perbankan syariah sehingga keuntungan atau bagi hasil dari pembiayaan perbakan syariah menurun atau bahkan terjadi defisit. Pembiayaan perbankan syariah sektor industri ini mencangkup pembiayaan perbankan sektor industri besar dan sedang.

Koefisien regresi Non Performing Financing sektor industri bernilai positif. Menurut Latan 2013 pada bukunya yang berjudul Analisis Multivariat Teknik dan Aplikasi Menggunakan Program SPSS 20 jika dikontektualkan tidak reliabel, mengingat jumlah Non Performing Financing sektor industri tidak mungkin positif karena secara faktanya kredit macet akan berpengaruh negatif kepada pembiayaan perbankan syariah hal ini sesuai dengan latan 2013 pada bukunya yang berjudul Analisis Multivariat Teknik dan Aplikasi Menggunakan Program SPSS 20. Pembiayaan perbankan syariah sektor industri ini mencangkup pembiayaan perbankan sektor industri besar dan sedang.

Koefisien regresi dana bank syariah di PUAS (ln_PUAS) bernilai positif. Menurut Fatwa DSN No. 37 dan Iska 2012 pada bukunya yang berjudul Sistem Perbankan Syariah Di Indonesia dalam Perspektif Fikih Ekonomi bahwa dana bank syariah di PUAS (ln_PUAS) naik maka pembiayaan perbankan syariah sektor industri (ln_PI) juga akan mengalami kenaikan. Begitu pula pada saat dana bank syariah di PUAS (ln_PUAS) turun maka pembiayaan perbankan syariah sektor industri (ln_PI) akan mengalami penurunan. Kenaikan dana bank syariah di PUAS (ln_PUAS) 1 Milyar rupiah akan menaikkan pembiayaan perbankan syariah sektor industri (ln_PI) sebesar 0,06 Milyar Rupiah dan sebaliknya, penurunan dana bank syariah di PUAS (ln_PUAS) 1 Milyar Rupiah akan menurunkan pembiayaan perbankan 
syariah sektor industri (ln_PI) sebesar 0,06 Milyar Rupiah. Pembiayaan perbankan syariah sektor industri ini mencangkup pembiayaan perbankan sektor industri besar dan sedang.

Koefisien regresi Equivalent Rate Murabahah (ln_ER_M) bernilai positif. Menurut Iska 2012 pada bukunya yang berjudul Sistem Perbankan Syariah Di Indonesia dalam Perspektif Fikih Ekonomi bahwa Equivalent Rate Murabahah (In_ER_M) naik maka pembiayaan perbankan syariah sektor industri (ln_PI) juga akan mengalami kenaikan. Begitu pula pada saat Equivalent Rate Murabahah (ln_ER_M) turun maka pembiayaan perbankan syariah sektor industri (ln_PI) akan mengalami penurunan. Kenaikan Equivalent Rate Murabahah (ln_ER_M) 1 milyar rupiah akan menaikkan pembiayaan perbankan syariah sektor industri (ln_PI) sebesar 12,09 Milyar Rupiah dan sebaliknya, penurunan Equivalent Rate Murabahah (ln_ER_M) 1 Milyar Rupiah akan menurunkan pembiayaan perbankan syariah sektor industri (ln_PI) sebesar 12,09 Milyar Rupiah. Pembiayaan perbankan syariah sektor industri ini mencakup pembiayaan perbankan sektor industri besar dan sedang.

Koefisien regresi Angkatan Kerja sektor Industri (ln_AKi) bernilai positif. Menurut penelitian hutasuhut 2006 pada jurnalnya yang berjudul Analisis FaktorFaktor Yang Mempengaruhi Pertumbuhan Industri Non Migas Di Provinsi Sumatera Utara bahwa Angkatan Kerja sektor Industri (ln_AKi) naik maka pembiayaan perbankan syariah sektor industri (ln_PI) juga akan mengalami kenaikan. Begitu pula pada saat Angkatan Kerja sektor Industri (ln_AKi) turun maka Pembiayaan perbankan syariah sektor industri (ln_PI) akan mengalami penurunan. Kenaikan Angkatan Kerja sektor Industri (ln_AKi) 1 juta jiwa akan menaikkan pembiayaan perbankan syariah sektor industri (ln_PI) sebesar 67,45 Milyar Rupiah dan sebaliknya, penurunan Angkatan Kerja sektor Industri (ln_AKi) 1 juta jiwa akan menurunkan Pembiayaan perbankan syariah sektor industri (ln_PI) sebesar 67,45 Milyar Rupiah. Pembiayaan perbankan syariah sektor industri ini mencangkup pembiayaan perbankan sektor industri besar dan sedang.

Koefisien regresi Dana Pihak Ketiga (ln_DPK) bernilai positif. Menurut Iska 2012 pada bukunya yang berjudul Sistem Perbankan Syariah Di Indonesia dalam Perspektif Fikih Ekonomi bahwa Dana Pihak Ketiga (ln_DPK) naik maka Pembiayaan perbankan syariah sektor industri (ln_PI) juga akan mengalami kenaikan. Begitu pula pada saat Dana Pihak Ketiga (ln_DPK) turun maka Pembiayaan perbankan syariah sektor industri (ln_PI) akan mengalami penurunan. Kenaikan jumlah Dana Pihak Ketiga (ln_DPK) 1 Milyar Rupiah akan menaikkan Pembiayaan perbankan syariah sektor industri (ln_PI) sebesar 0,04 Milyar Rupiah dan sebaliknya, penurunan jumlah Dana Pihak Ketiga (ln_DPK) 1 Milyar Rupaih akan menurunkan Pembiayaan perbankan syariah sektor industri (ln_PI) sebesar 0,04 Milyar Rupiah. Pembiayaan perbankan syariah sektor industri ini mencangkup pembiayaan perbankan sektor industri besar dan sedang.

\section{KESIMPULAN DAN IMPLIKASI}

Perkembangan perbankan syariah mengalami peningkatan dari tahun 2009 2015 dilihat dari meningkatnya jumlah tenaga kerja, jumlah pekerja, jumlah dana bank syariah di Indonesia dan jumlah pembiayaan perbankan syariah berazaskan akad, penggunaan dan golongan.

Berdasarkan hasil perhitungan dengan menggunakan SPSS 22 melalui teknik regresi berganda pada pendekatan OLS, H0 ditolak. Artinya Inflasi, NPF sektor industri, dana bank syariah di PUAS, Equivalent Rate Murabahah, Angkatan Kerja Sektor Industri dan DPK 
berpengaruh terhadap pembiayaan perbankan syariah sektor industri. Pada Faktor inflasi menjadi faktor utama karena memiliki nilai yang lebih unggul dibandingkan dengan faktor lainnya. Kenaikan harga-harga secara global atau makro akan menyebabkan pembiayaan perbankan syariah pada sektor industri menurun dikarenakan counterparty atau nasabah atau perusahaan industri harus menaikkan harga barang produksi. Disisi lain inflasi juga berpengaruh kepada masyarakat yang menyebabkan daya beli masyarakat menurun. Dengan penurunan daya beli masyarakat akan menurunkan keuntungan perusahaan sektor industri yang mana barang produksinya tidak terjual sebagaimana mestinya. Hal ini dapat akan merugikan bank syariah dan perusahaan sektor industri dalam pembiayaan sektor industri karena keuntungan atau bagi hasil dari pembiayaan perbankan syariah menurun atau bahkan dapat terjadi defisit. Sektor industri yang menjadi ruang lingkup pembiayaan perbankan syariah pada penelitian ini yaitu sektor industri besar dan sedang (IBS).

\section{DAFTAR PUSTAKA}

Abdullah,2015. Metodologi Penelitian Kuantitatif, Yogyakarta : Aswaja Pressindo.

Brink, Pamela,2000. Langkah Dasar Dalam Perencanaan Riset Keperawatan, Jakarta : Kedokteran EGC.

Dahrani. Jurnal Riset Akuntansi Dan Bisnis, 2014. Analisis Mekanisme Pembiayaan Mudharabah Pada PT.Bank BNI Syariah Kantor Cabang Medan. Medan.

Direktorat Perbankan Syariah,2015. Statistik Perbankan Syariah, Jakarta : Bank Indonesia.

Harinaldi,2005. Prinsip-prinsip Statistik Untuk Teknik dan Sains, Jakarta : Erlangga.

Hutasuhut, Saidun. Jurnal Sistem Teknik Industri, 2006. Analisis Faktor-
Faktor Yang Mempengaruhi

Pertumbuhan Industri Non Migas Di

Provinsi Sumatera Utara. Medan.

Iqbal, Muhammad. PDF 2010. Pengolahan

Data dengan Regresi Linear

Berganda. Bandung

Iska, Syukri, 2012. Sistem Perbankan Syariah Di Indonesia dalam Perspektif Fikih Ekonomi, Yogyakarta : Fajar Media Press.

Juanda ,2009. Ekonometrika Permodelan dan Pendugaan, Bogor : IPB Press.

Karim, Adiwarman, 2004, Bank Islam Analisis Fiqih dan Keuangan, Jakarta : PT.Raja Grafindo Persada.

Karim, Adiwarman, 2008, Ekonomi Makro Islam, Jakarta : PT.Raja Grafindo Persada

Kusuma, Hadri. Jurnal Kajian Bisnis dan Manajemen, 2005. Analisis Proporsi Perolehan Fee Based Income Bank Pembangunan Daerah (BPD) di Indonesia (Periode 1999-2003).

Latan, 2013. Analisis Multivariat Teknik dan Aplikasi Menggunakan Program SPSS 20, Bandung : ALFABETA

Lesmana, Iwan. Jurnal PESAT (Psikologi, Ekonomi, Sastra, Arsitek dan Sipil), 2007. Risiko Strategik, Risiko Legal. Risiko Kepatuhan Dan Risiko Reputasi Dalam Industri Perbankan Di Indonesia. Depok.

Mutamimah. Jurnal Bisnis dan Ekonomi, 2012. Analisis Eksternal dan Internal Dalam Menentukan Non Performing Financing Bank Umum Syariah Di Indonesia. Semarang.

Nugraha, M.Fakhri, 2014. Analisis FaktorFaktor Yang Mempengaruhi Pembiayaan Perbankan Syariah Pada Sektor Jasa Dunia Usaha Di Indonesia. Skripsi Program Studi Ilmu Ekonomi Syariah. Fakultas Ekonomi dan Manajemen Intitut Pertanian Bogor.

Pramesti, Getut, 2014. Kupas Tuntas Data Penelitian Dengan SPSS 22, Jakarta : PT Elex Media Komputindo.

Samadi, 2007. Geografi 3, Depok : Image D3. 
Santoso, Singgih, 2010. Seri Solusi Bisnis Berbasis IT Menggunakan SPSS Untuk Statistik Non Parametrik, Jakarta : PT Elex Media Komputindo.

Setiadi , Pompong. Jurnal Mitra Ekonomi dan Manajemen Bisnis, 2010, Analisis Hubungan Spread of Interest Rate, Fee Based Income, dan Loan To Deposit Ratio dengan ROA
Pada Perbankan Di Jawa Timur. Jawa Timur.

Suharyadi, 2009. Statistik Untuk Ekonomi Dan Keuangan Modern Edisi 2, Jakarta : Salemba Empat.

www.bi.go.id Maret,2016

www.bps.go.id Maret,2016

www.kemenperin.com Maret 2016 